\title{
Numerical Simulations in Obtaining Drag Reduction for Projectile with Base Bleed
}

\author{
Habib Belaidouni ${ }^{1)}$ \\ Saša Živković ${ }^{2)}$ \\ Marija Samardžić ${ }^{2)}$
}

\begin{abstract}
An artillery projectile in flight produces a low pressure area immediately behind the projectile which creates a force called base drag which lessens the velocity of the projectile. It is known that theoretically this base resistance can be reduced or even eliminated by allowing a stream of hot gas to flow out of the base surface of the projectile in a suitable manner. The effect produced by this stream of hot gas is called base-bleed effect. The internal ballistic calculation of existing base bleed configuration is presented in the paper. A numerical simulation of axisymmetric body projectiles was obtained with the Reynolds Averaged Navier-Stokes (RANS) computational fluid dynamics software (CFD). Also, two turbulence models were tested and validated with the semi empirical prediction. The realizable $k-\varepsilon$ turbulence model was chosen for calculation of aerodynamic drag of the projectile with and without base bleed effect. Computed result show a drag reduction with base bleed of about $12 \%$ in supersonic flow regime
\end{abstract}

Key words: artillery projectile, base bleed projectile, projectile aerodynamics, aerodynamic thrust, numerical simulation, computational fluid dynamics.

\section{Introduction}

$\mathrm{T}$ HE base drag as a component of the total drag arises from vortices and turbulence in the air. These vortices produce a lowering of the air pressure behind the projectile. In addition to this, aerodynamic bodies such as projectiles, missiles and rockets, generally, undergo a significant deterioration of flight performance by the drag. For these types of flight bodies the drag in the base region has the most significant contribution to total drag. At transonic speeds, for example, base drag constitutes a major portion up to $50 \%$ of the total drag for typical projectiles at the speed range of Mach 0.9 [1]. Therefore the base drag should be considered separately from the other drag components. For this reason, the minimization of base drag has been an important issue to date, and considerable effort has been made to find suitable techniques for obtaining a low base drag shell design.

During a projectile flight the reverse flow directly behind the projectile base is shown in Figure 1. The large turning angle behind the base causes separation and formation of reverse flow known as the recirculation region or the separation bubble [2-3]. The size of the recirculation determines the turning angle of the external flow and therefore the strength of the expansion waves. A smaller recirculation region causes the flow sharp turning, leading to a stronger expansion wave and lower pressures behind the base. Therefore, small separated region causes larger base drag than large regions.

In recirculation region the point along the axis of symmetry, where the stream wise velocity diminishes, is called a shear layer reattachment point. As the shear layer reattaches, the flow is forced to turn along the axis of symmetry, causing the formation of a reattachment shock.
Figure 2 shows that injecting small amounts of gas into the flow field behind the base of the projectile will split the originally large recirculation zone into two parts. One recirculation region remains at the symmetry axis and the other one is formed right behind the base corner [4-7]. As the mass flow rate increases, the recirculation zone at the axis is pushed further out and the other one at the base corner becomes larger. If the mass flow rate is increased away, the recirculation region near the axis disappears and the base bleed follows a straight path.

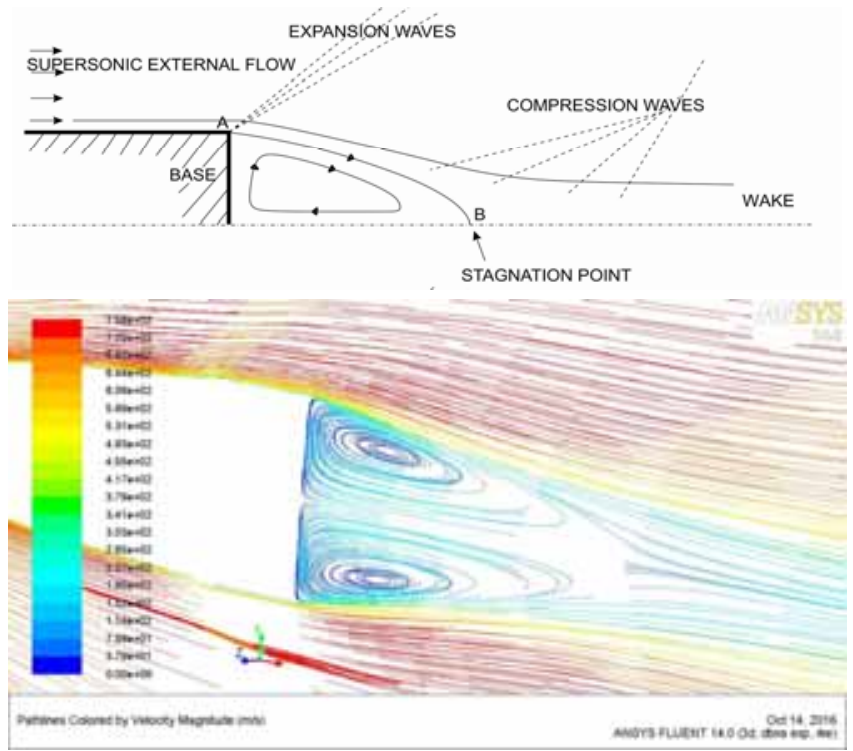

Figure 1. Streamlines near the base of projectile without base bleed (plane of symmetry of the projectile) [8]

\footnotetext{
1) University of Defense, Military Academy, Pavla Jurišića Šturma 33, 11000 Belgrade, SERBIA

2) Military Technical Institute (VTI), Ratka Resanovića 1, 11132 Belgrade, SERBIA

Correspondence to: Marija Samardžić; e-mail: majasam@ptt.rs
} 

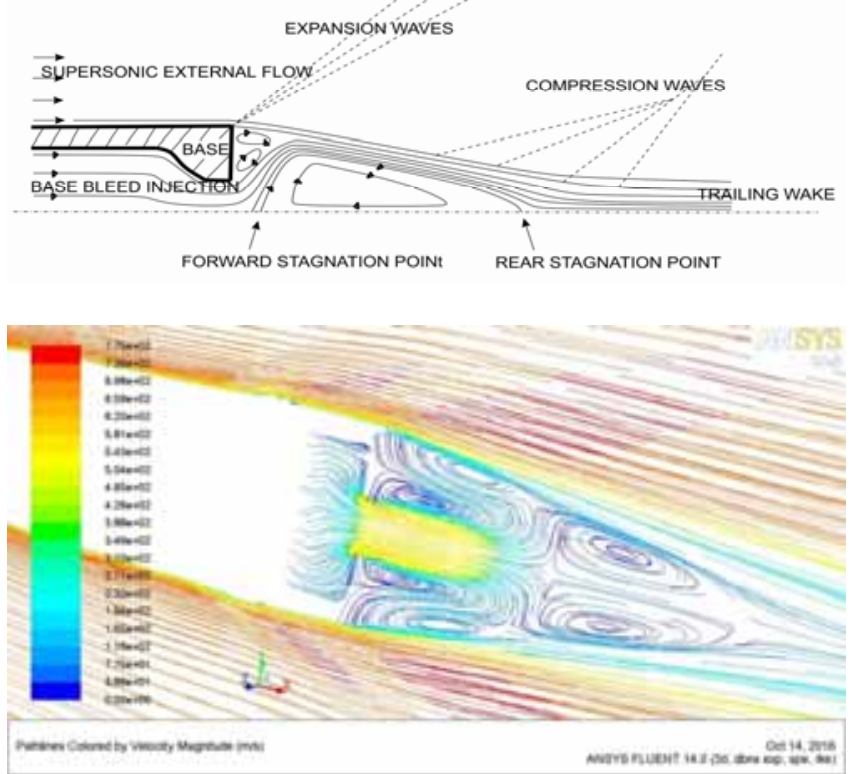

Figure 2. Streamlines near the base of projectile with base bleed (plane of symmetry of the projectile) [8]

\section{Internal ballistic calculation}

The gas generator for the $122 \mathrm{~mm}$ base bleed projectile housed in the afterbody is presented in this paper. The gas generator cross section is shown in Fig.3.
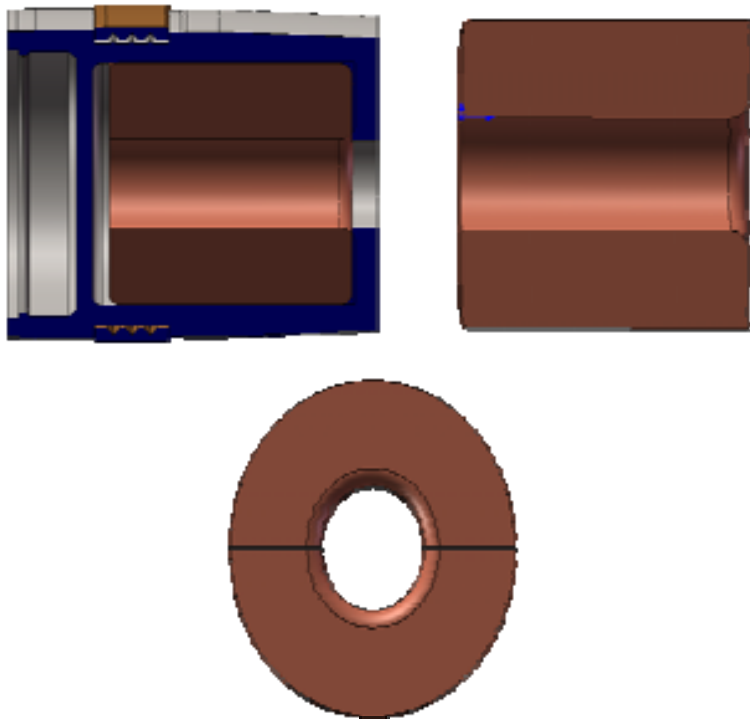

Figure 3. Scheme of the gas generator unit and propellant grain

The gas generator contains two identical solid propellant grains. These two elements provide an internal combustion surface consisting of two cylindrical surfaces and four flat surfaces, which results in total decreasing burning surface area.

For the injection mass flow rate, the dimensionless injection parameter $I$ is generally used. The parameter $I$ is defined as the bleed mass flow rate, $\dot{m}_{p}$, normalized by the product of the base area, $A_{\text {base }}$, and the free stream mass flux, eq. (1) $[9,10]$ :

$$
I=\frac{\dot{m}_{p}}{\rho_{\infty} V_{\infty} A_{\text {base }}}
$$

where $\rho_{\infty}$ is free stream density, and $V_{\infty}$ is free stream velocity.
Mass flow produced by the combustion of the gas generator (GG) is shown in Fig.4.

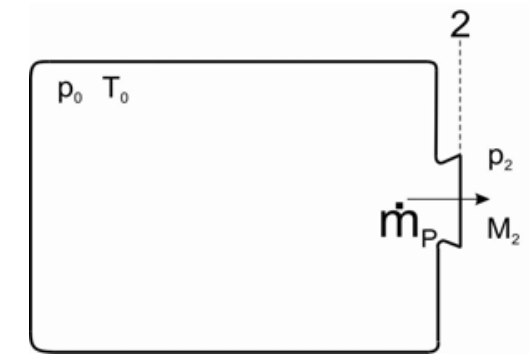

Figure 4. Mass flow produced by combustion of GG

Designed GG is tested in the Military Technical Institute (MTI) laboratory "Technicum" in Baric (Belgrade). Experimentally obtained curve of chamber gauge pressure, $p$, vs. time, $t$, is shown in Fig.5. According to the experimental curve several values of the absolute pressure denoted in Fig. 6 were chosen for the mass flow rate calculation. In Fig.6, $p_{c}$ is chamber pressure.

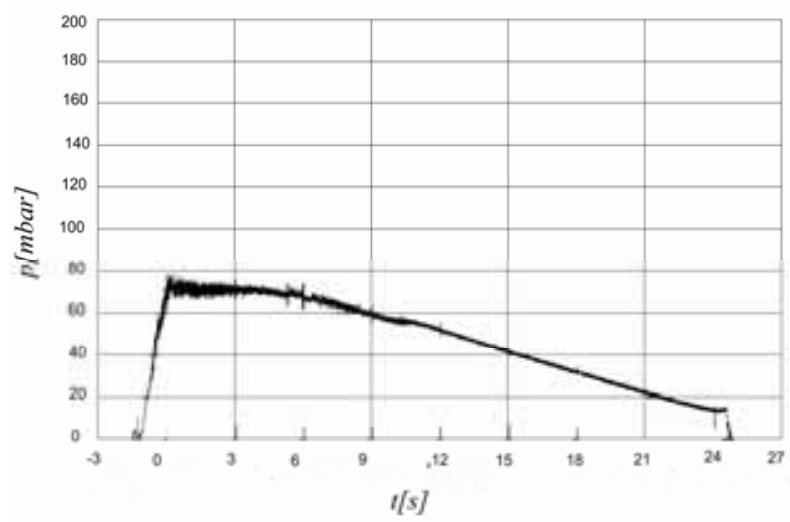

Figure 5. Experimental chamber gauge pressure vs. time for gas generator $122 \mathrm{~mm}$

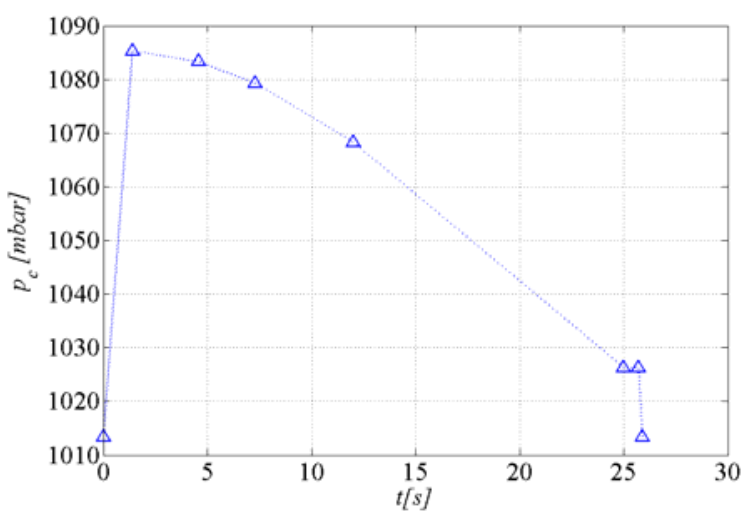

Figure 6. Absolute chamber pressure vs. time for gas generator $122 \mathrm{~mm}$

Flow out of the combustion products bleed through orifice is subsonic. In dependency on the thermo-chemical characteristics of propellant and using gas dynamics relations can be written as:

$$
\begin{gathered}
M_{2}(p)=\sqrt{\frac{2}{k-1}\left[\left(\frac{p_{0}}{p_{2}}\right)^{\frac{k-1}{k}}-1\right]} \\
T_{2}(p)=\frac{T_{0}}{1+\frac{k-1}{2} M_{2}(p)^{2}}
\end{gathered}
$$


where $T_{0}$ is total temperature, $p_{0}$ is total pressure, $k$ is ratio of specific heats, $T_{2}$ is temperature at the section 2 (nozzle exit), $p_{2}$ is pressure at the section 2 and $M_{2}$ is the Mach number at nozzle exit.

The products mass flow rate as a function of the pressure in combustion chamber is obtained as:

$$
\dot{m}_{p}(p)=\rho_{2}(p) V_{2}(p) A_{2}
$$

where $V_{2}$ is velocity at the section 2 $\left(V_{2}(p)=M_{2}(p) \sqrt{k \cdot R \cdot T_{2}(p)}\right), \rho_{2}$ is density at the section 2 $\left(\rho_{2}(p)=\frac{p_{2}}{R \cdot T_{2}(p)}\right)$, and $R$ is gas constant.

Required combustion products mass flow rate (Fig.7) can be achieved by an appropriate internal ballistic design of GG.

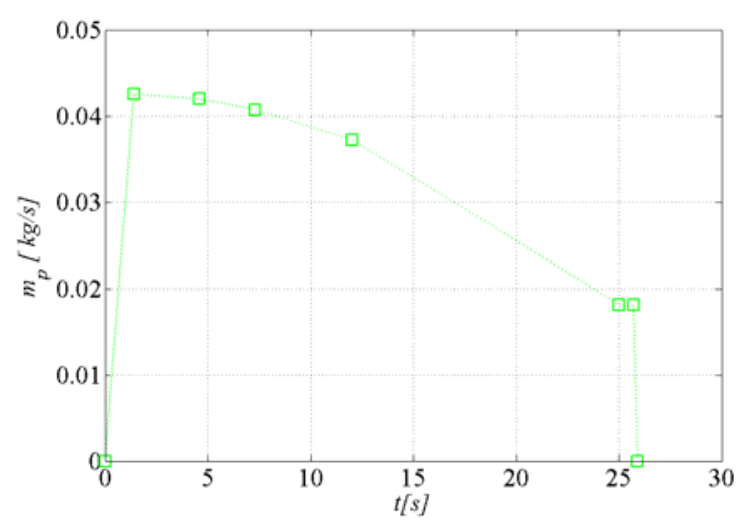

Figure 7. Mass flow rate change vs. time.

In dependency on projectiles trajectory altitude all influential functions can be expressed as a function of time (using altitude $y(t)$ and speed $M(t)$ parameters: air density $\rho_{\infty}(y)=\rho_{\infty}(t)$ and temperature $\left.T(y)=T(t)\right)$. Finally, optimal mass flow rate change in time can be determined using eq. (5):

$$
\dot{m}_{p}(t)=I(M(t)) \rho_{\infty}(t) \sqrt{k R T(t)} M(t) A_{\text {base }}
$$

\section{Aerodynamic drag coefficient}

The total aerodynamic drag of projectile can be divided into three components consisting of the pressure drag $C_{D p}$, viscous drag $C_{D v}$, and base drag $C_{D B}$. This dependence is shown by eq. (6):

$$
C_{D}=C_{D p}+C_{D v}+C_{D B}
$$

The mass flow from the gas generator reduces the base drag component. The base drag component can be expressed as a function of the base pressure $p_{B}$, pressure free stream flow field $p_{\infty}$ and the Mach number $M$.

$$
C_{D B}=\frac{2\left(1-p_{B} / p_{\infty}\right)}{k M^{2}}
$$

From eq. (7), the difference between the base drag component for a projectile without base bleed $C_{D B_{0}}$, and projectile with base bleed $C_{D B B}$, can be written as:

$$
\Delta C_{D}=C_{D B_{0}}-C_{D B B}
$$

$$
C_{D B}=\frac{2\left(\frac{p_{B B}}{p_{\infty}}-\frac{p_{B_{0}}}{p_{\infty}}\right)}{k \cdot M^{2}}
$$

where $p_{B_{0}}$ is a base pressure of projectile without base bleed, $p_{B B}$ is a base pressure of projectile with base bleed.

\section{Numerical solution}

The aerodynamic CFD prediction simulation of $122 \mathrm{~mm}$ projectile model with base bleed, shown in Fig.8, was done numerically using the software GAMBIT 2.4 and ANSYS FLUENT 14 [8].

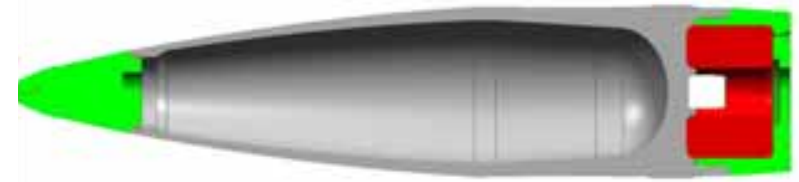

Figure 8. Model of a projectile with base bleed [11]

The mathematical model is based on the RANS including conservation of mass, momentum, energy and ideal gas equation of state. Basic assumptions of the mathematical model are given in the Equations (10-14) [12]: continuity:

$$
\frac{\partial}{\partial x_{i}}\left(\overline{\rho u_{i}}\right)=0
$$

momentum:

$$
\begin{aligned}
\frac{\partial}{\partial x_{j}}\left(\overline{p u_{i} u_{j}}\right)= & -\frac{\partial \bar{p}}{\partial x_{i}}+\frac{\partial}{\partial x_{j}}\left[\mu\left(\frac{\partial \bar{u}_{i}}{\partial x_{j}}+\frac{\partial \bar{u}_{j}}{\partial x_{i}}-\frac{2}{3} \delta_{i j} \frac{\partial \bar{u}_{i}}{\partial x_{i}}\right)\right]+ \\
& +\frac{\partial}{\partial x_{j}}\left(-\overline{p u}_{i}^{\prime} \bar{u}_{j}^{\prime}\right)
\end{aligned}
$$

energy:

$$
\begin{aligned}
& \frac{\partial}{\partial t}\left(p h_{0}\right)+\frac{\partial}{\partial x_{j}}\left(p h_{0} u_{j}\right)= \\
& =\frac{\partial p}{\partial t}+\frac{\partial}{\partial x_{j}}\left(u_{i}\left(\frac{\partial u_{i}}{\partial x_{j}}+\frac{\partial u_{j}}{\partial x_{i}}-\frac{2}{3} \delta_{i j} \frac{\partial u_{i}}{\partial x_{i}}\right)+\lambda \frac{\partial T}{\partial x_{j}}\right)
\end{aligned}
$$

ideal gas:

$$
p=\rho R T
$$

where $\bar{p}$ is mean pressure, $\rho$ is mean density, $\mu$ is molecular viscosity, $h_{0}$ is total enthalpy, $\lambda$ is thermal conductivity.

Reynolds stresses are given as,

$$
-\bar{\rho} \bar{u}_{i}^{\prime} \bar{u}_{j}^{\prime}=\mu_{t}\left(\frac{\partial \bar{u}_{i}}{\partial x_{j}}+\frac{\partial \bar{u}_{j}}{\partial x_{i}}\right)-\frac{2}{3}\left(\rho k+\mu_{t} \frac{\partial \bar{u}_{i}}{\partial x_{i}}\right) \delta_{i j}
$$

where $\mu_{t}$ is turbulent or eddy viscosity, $k$ is turbulent kinetic energy. To correctly account for turbulence, Reynolds stresses are modeled in order to achieve closure of eq.n (11). The method of modeling employed utilizes the Boussinesq hypothesis to relate the Reynolds stresses to the mean velocity gradients within the flow.

The numerical simulation was done with two-equation realizable $k-\varepsilon$ turbulence model. Even the Spalart-Allmaras $S A$ model was designed specifically for aerospace applications 
[13], we concluded that the realizable $k-\varepsilon$ turbulence model shows very good agreement with two semi-empirical methods. The turbulent viscosity in the model is computed through the solution of two additional transport equations for the turbulent kinetic energy, and the turbulent specific dissipation rate, $\varepsilon$, [12]. The second model of the numerical simulation was four-equation transitional $S S T$ turbulence model.

The numerical discretization of the computational domain around the model was done with hybrid mesh of tetrahedral and hexahedra cells. The ellipsoidal computational domain is created with the longitudinal axis of 40 referent model diameter and lateral axes of 25 referent diameter, Fig.9. The spatial discretization schemes of the equation were the second order upwind. Computational domain was consisted of about 3 million of cells.

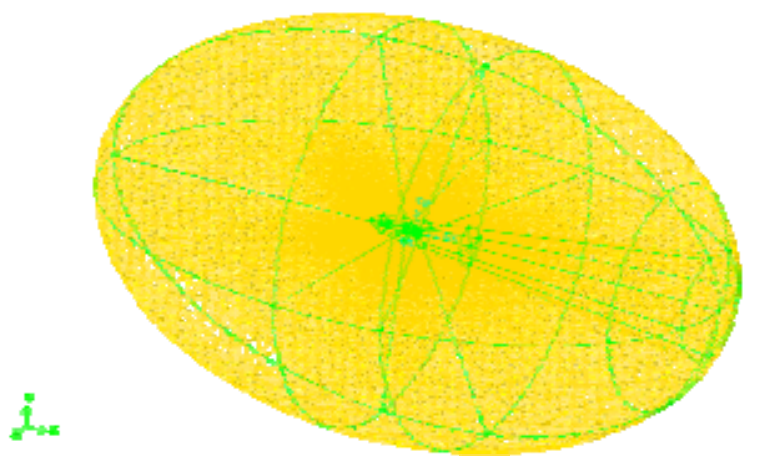

Figure 9. Mesh of a numerical domain for the $122 \mathrm{~mm}$ projectile with base bleed

The criteria of convergence were constant values of aerodynamic coefficients of axial force and residuals less than $5 \cdot 10^{-4}$.

The mesh resolution near the wall of the model applied in the numerical simulations is shown in Fig. 10.

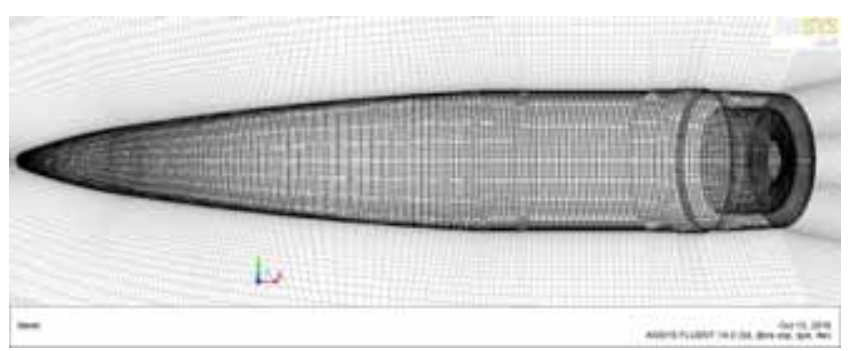

Figure 10. Mesh resolution near the wall of the $122 \mathrm{~mm}$ projectile with base bleed

The axial aerodynamic predictions are done for Mach number at different flight regimes $0.99 \leq M \leq 2.1$. Numerical steady state simulations with two turbulences model $k-\varepsilon$ and $S S T$ were done for each Mach number on a higher processor computing resource.

Nine cases of elements trajectory of the projectile are investigated, for every case, point on trajectory, velocity of projectile, air ambient pressure and temperature are chosen. For example the first case corresponds to the beginning of the base bleed operation. In this case, the air ambient pressure is $101235 \mathrm{~Pa}$ and air temperature is $288 \mathrm{~K}$. This parameter corresponds to zero altitude. At the moment when the base bleed starts to operate, the projectile velocity was $715.0 \mathrm{~m} / \mathrm{s}$ and mass flow rate of bleeding combustion products was 0.05 $\mathrm{kg} / \mathrm{s}$.

For the other cases, projectile velocities, air pressure, mass flow rates of bleeding combustion products are shown in Table 1.
Table 1: Elements of the projectile $122 \mathrm{~mm}$ trajectory in the shooting at maximum range during the base bleed operation.

\begin{tabular}{|c|c|c|c|c|c||}
\hline $\begin{array}{c}\text { Time of } \\
\text { flight } \\
t[\mathrm{~s}]\end{array}$ & $\begin{array}{c}\text { Altitude } \\
{[\mathrm{m}]}\end{array}$ & $\begin{array}{c}\text { Velocity of } \\
\text { projectile } \\
V[\mathrm{~m} / \mathrm{s}]\end{array}$ & $\begin{array}{c}\text { Air ambiant } \\
\text { pressure } \\
p_{\infty}[\mathrm{Pa}]\end{array}$ & $\begin{array}{c}\text { Temperature } \\
T[\mathrm{k}]\end{array}$ & $\begin{array}{c}\text { Mass flow } \\
\text { rate } \\
\mathrm{kg} / \mathrm{s}]\end{array}$ \\
\hline \hline 2.54 & 1237.1 & 633.9 & 87320 & 280 & 0.0456 \\
\hline 5.18 & 2352.5 & 569.7 & 76080 & 273 & 0.0409 \\
\hline 9.72 & 3954.7 & 484.4 & 62070 & 262.8 & 0.0330 \\
\hline 14.53 & 5278.1 & 411.5 & 52040 & 253.6 & 0.0246 \\
\hline 18.08 & 6033.3 & 366.5 & 46970 & 249 & 0.0184 \\
\hline 21.90 & 6668.4 & 326.3 & 43010 & 244.9 & 0.0117 \\
\hline 22.68 & 6774.4 & 319.5 & 42380 & 244.1 & 0.0103 \\
\hline 24.00 & 6934.5 & 309.9 & 41440 & 243.1 & 0.0080 \\
\hline
\end{tabular}

\section{Results and discussion}

The research of aerodynamic drag, presented in the paper, is consisted of two groups of aerodynamic predictions: the semiempirical aerodynamic predictions MTI and ADK0 [14, 15] and numerical prediction with code of computational fluid dynamics CFD incorporated into ANSYS FLUENT software [8].

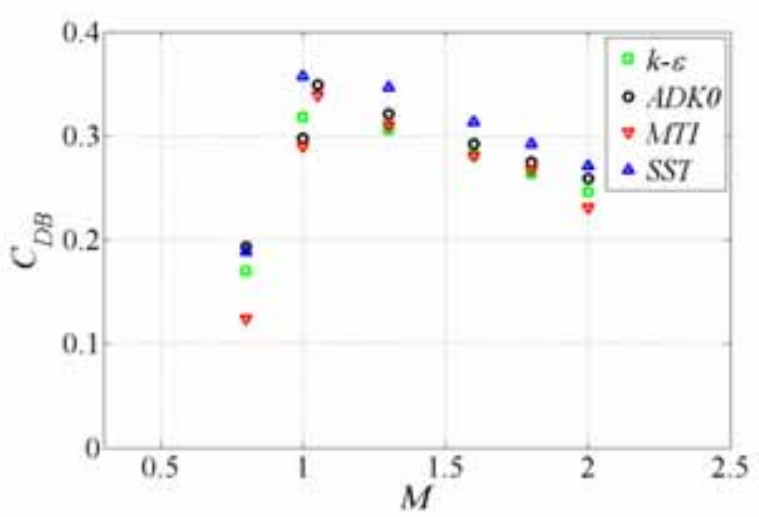

Figure 11. Aerodynamic coefficient vs. the Mach number for the $122 \mathrm{~mm}$ projectile

The compared results of the axial force coefficient $C_{D B}$ obtained by aerodynamic semi-empirical predictions and two sets of numerical simulations $k-\varepsilon$ and SST are shown in Fig.11.

The presented values of axial force coefficient show very good agreement to semi empirical data for the case the $k-\varepsilon$ turbulence model is utilized. However, the four-equation SST was implemented with no significant differences noted with the semi-empirical data $[14,15]$.

A turbulence $k-\varepsilon$ realizable model was selected for simulation projectile with base bleed because of the best agreement with $C_{D B}$.

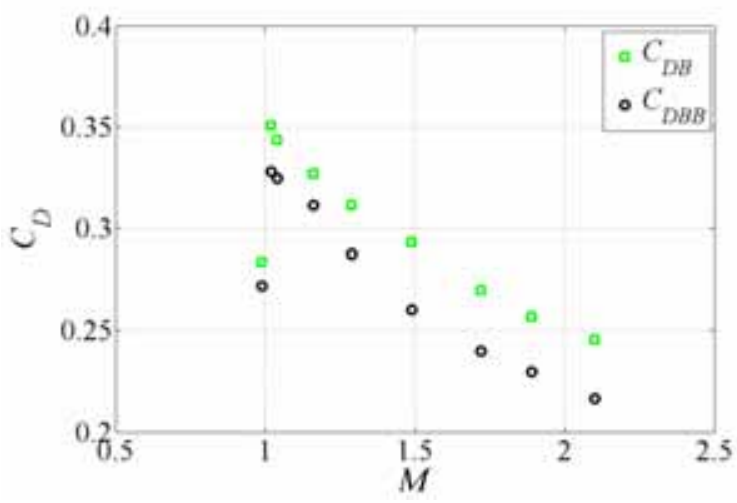

Figure12. Effect of base bleed on drag coefficient 
The values of predicted axial aerodynamic coefficient, $C_{D B O}$ and values of axial aerodynamic coefficient with reduction using the gas generator unit, $C_{D B B}$, vs. the Mach number are presented in Fig.12. It is shown that there is an average reduction for all flow regimes, especially in supersonic, which is within the range of $4 \%$ to almost $12 \%$ as shown in Table 2.

Table 2: Drag coefficient reduction expressed in percentages

\begin{tabular}{|c|c|c|c||}
\hline Cases & $C_{D B 0}$ & $C_{D B B}$ & $\Delta \mathrm{C}_{D} \%$ \\
\hline 1 & 0.2456 & 0.2165 & 11.85 \\
2 & 0.2569 & 0.2298 & 10.55 \\
3 & 0.2698 & 0.2400 & 11.05 \\
4 & 0.2931 & 0.2603 & 11.20 \\
5 & 0.3114 & 0.2875 & 7.68 \\
6 & 0.3267 & 0.3112 & 4.75 \\
7 & 0.3434 & 0.3246 & 5.47 \\
8 & 0.3507 & 0.3280 & 6.47 \\
9 & 0.2837 & 0.2721 & 4.09 \\
\hline
\end{tabular}

Reducing the base drag accomplished by the fill up the wake zone behind the projectile and thus increased the base pressure. Increased base pressure reduces the base drag and gives increased shooting distance for the projectile. The parameters of flow behind the projectile before and after injection of the hot gas produced by the gas generator are shown in Figures $13-15$.

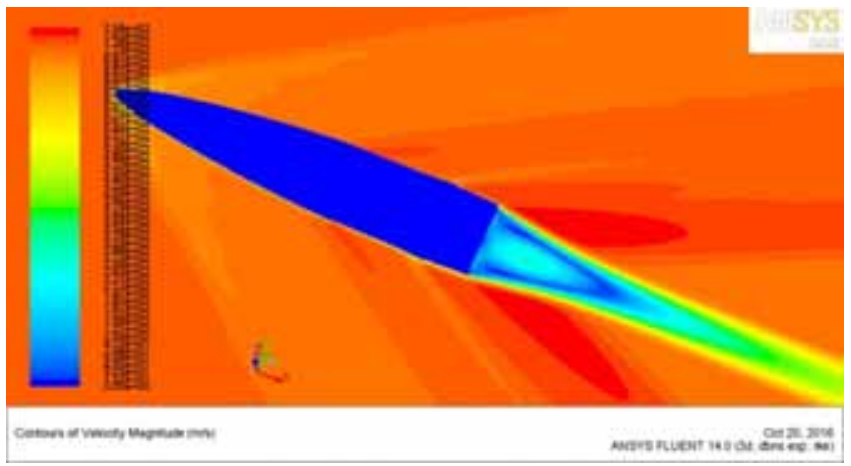

a) Before injection

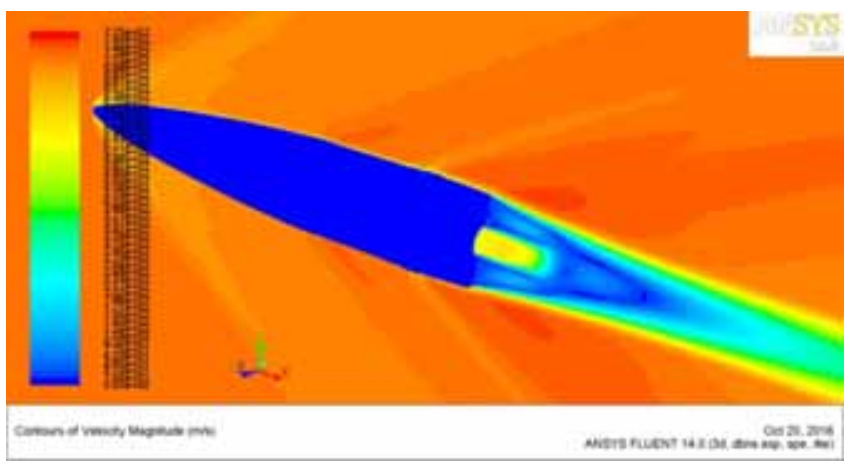

b) After injection

Figure 13. Velocity magnitude contours of projectile before and after injection for $M=2.1$

\section{Conclusion}

The 3D numerical computation was performed for the $122 \mathrm{~mm}$ projectile with and without base bleed at different values of the Mach number. A series of calculation drag coefficient was run for the $122 \mathrm{~mm}$ projectile with and without base bleed.

The simulations were performed for the zero of attack and Mach number range $0.99 \leq M \leq 2.1$. Mass flow rate and corresponding impulse were chosen from internal ballistic calculation based on the static tests of gas generator propellant.

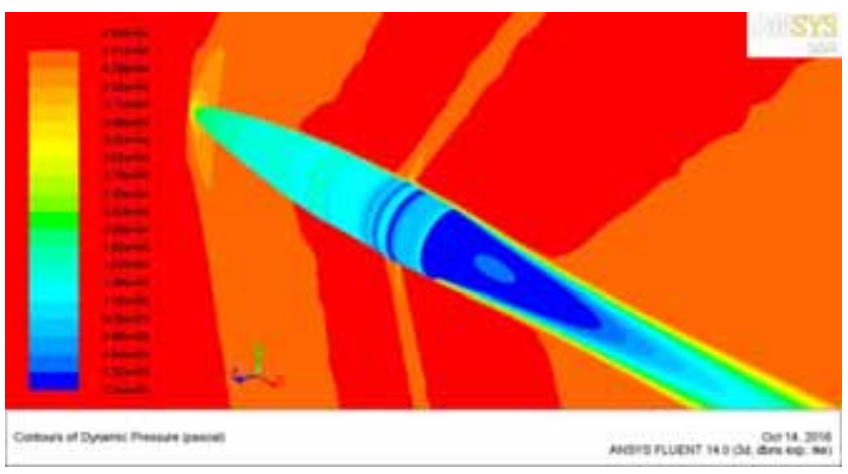

a) Before injection

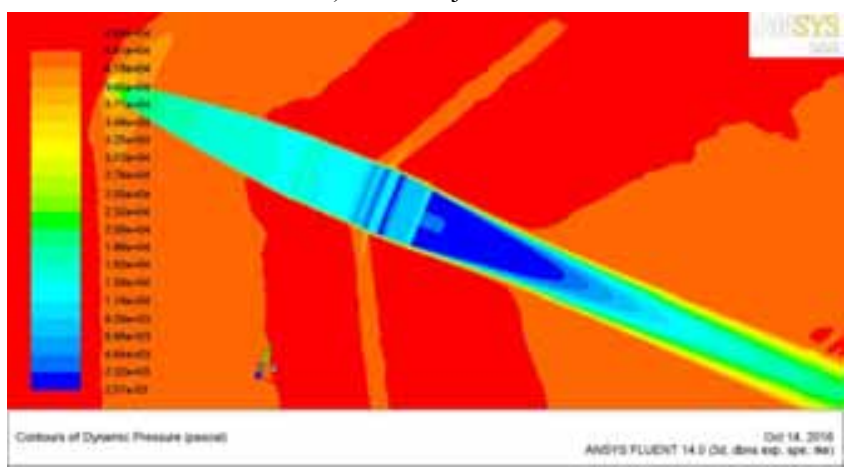

b) After injection

Figure 14. Dynamic pressure contours of projectile before and after injection for $M=1.16$

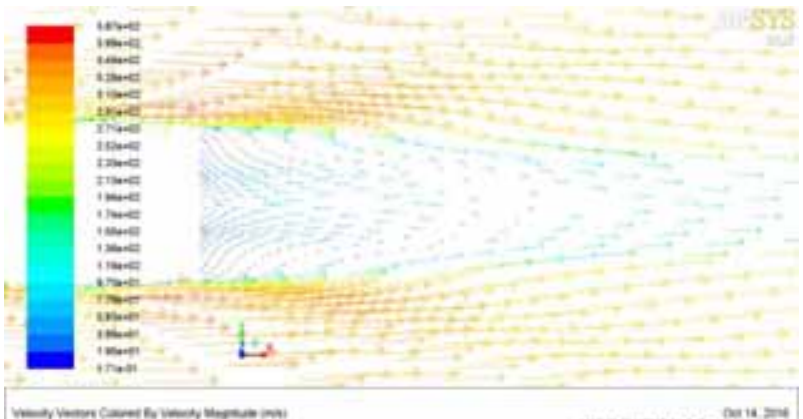

a) Before injection

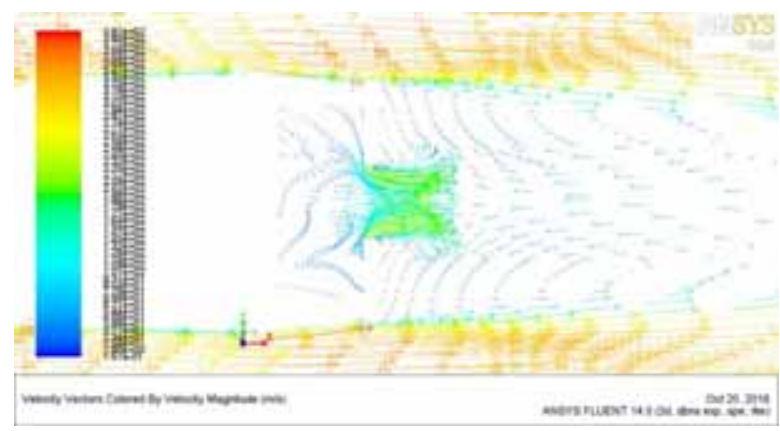

b) After injection

Figure 15. Dynamic pressure contours of projectile before and after injection for $M=0.99$

The influence of the base bleed flow effects on the drag coefficient was calculated. The computed drag coefficient of the projectile with and without base bleed showed a drag reduction with base bleed of about $12 \%$.

This investigation will be continued through studying the effect of base bleed on drag coefficient at different angles of attack, the influence of the base bleed effects on the lateral aero-dynamic coefficients, and especially dynamic derivatives and stability parameter. 


\section{References}

[1] SAHU, J. NIETUBICZ, C.J.: Navier-Stokes Computations of Projectile Base Flow with and without Mass Injection. AIAA Journal, 1985, Vol.23, No.9, pp.1348-1355.

[2] HEREIN, J. L., DUTTON, J. C.: Supersonic Base Flow Experiments in the Near Wake of a Cylindrical Afterbody. AIM Journal, 1994, Vol.32, No.1, pp.77-83.

[3] HERRIN, J. L., DUTTON, J. C.: Supersonic Near-Wake Afterbody Boattailing Effects on Axisymmetric Bodies. Journal of Spacecraft and Rockets, 1994, Vol.31, No.6, pp.1021-1028.

[4] CORTRIGHT, E. M., SCHROEDER, A. H.: Preliminary Investigation of Effectiveness of Base Bleed in Reducing Drag of Blunt-Base Bodies in Supersonic Stream, March 1951, NACA RM E51A26.

[5] REID, J., HASTINGS, R. C.: The Effect of a Central Jet on the Base Pressure of a Cylindrical Afterbody in a Supersonic Stream, Aeronautical Research Council (Great Britain), Reports and Memoranda,Dec. 1959, No.3224.

[6] BOWMAN, J. E., CLAYDEN, W. A.: Cylindrical Afterbodies in Supersonic Flow with Gas Ejection. AIAA Journal, 1967, Vol.5, No.6, pp.1524-1525.

[7] VAlENTINE, D. T., PRZIREMBEL, C. E. G.: Turbulent Axisymmetric Near-Wake at Mach Four with Base Injection. AIAA Journal, 1970, Vol.8, No.12, pp. 2279- 2280.

[8] Ansys Inc., ANSYS FLUENT 14.0 and GAMBIT 2.1 licensed to MTI, 2010
[9] BOWMAN, J. E., CLAYDEN, W.: A Reduction of Base Drag by Gas Ejection, R.A.R.D.E report 1969, 4/64.

[10] BELAIDOUNI, H., ŽIVKOVIĆ, S., KOZIĆ, M., SAMARDŽIĆ, M., BOUTEMDJET A.: Effect of Base Bleed on the Drag Reduction. In Proceedings of the $7^{\text {th }}$ International Scientific Conference on Defensive Technologies OTEH 2016, 6-7 October, 2016, Belgrade, SERBIA, ISBN 978-86-81123-82-9, pp.13-18.

[11] KUBBERUD, N., IVAR, J.: Extended Range of $155 \mathrm{~mm}$ Projectile Using an Improved Base Bleed Unit. Simulations and Evaluation. 26th International Symposium on Ballistics September 12-16, 2011 Miami, Florida, USA.

[12] MULVANY N.J., CHEN L., TU Y.J., ANDERSON B.: Steady-State Evaluation of Two-Equation RANS Turbulence Models for HighReynolds Number Hydrodynamic Flow Simulations, DSTRO-TR1564, DSTO Platform Sciences Laboratory,2004, Victoria, Australia.

[13] KOSTIĆ, Č.: Review of the Spalart-Allmaras Turbulence Model and its Modifications to Three-Dimensional Supersonic Configurations. Scientific Technical Review, ISSN 1820-0206, 2015,Vol. 65, No.1, pp. 43-49.

[14] JARAMAZ, S., INJAC, M.: Method of Calculation Range of Base Bleed Projectile. (in Serbian), Military Technical Institute, Belgrade, 1989.

[15] REGODIĆ, D.: External Ballistic. (in Serbian), Military Academy, 2006, Belgrade, Serbia.

\title{
Određivanje smanjenja otpora pomoću numeričke simulacije za projektil sa gasogeneratorom
}

\begin{abstract}
Pri letu artiljerijskog projektila dolazi do formiranja oblasti sa niskim pritiskom odmah iza baze projektila što dovodi do stvaranja baznog otpora koji utiče na smanjenje brzine projektila. Poznato je da bazni otpor može biti smanjen ili čak potuno eliminisan formiranjem struje toplog gasa iza baze projektila. Dejstvo koje se postiže ovom strujom toplog gasa zove se efekat isticanja iz gasogeneratora. Unutrašnji balistički proračun konfiguracije sa gasogeneratorom prikazan je u ovom radu. Numerička simulacija osnosimetričnog projektila urađena je korišćenjem softvera Reynolds Averaged Navier-Stokes (RANS) computational fluid dynamics software (CFD). Takođe, urađena su ispitivanja za dva turbulentna modela pomoću poluempiriskih metoda. Realizable k- $\varepsilon$ turbulence model korišćen je za proračun aerodinamičkog otpora projektila sa i bez gasogeneratora. Dobijeni rezultati pokazuju smanjenje otora za oko $12 \%$ u supersoničnom režimu strujanja za konfiguraciju sa gasogeneratorom.
\end{abstract}

Ključne reči: artiljerijski projektil, projektil sa gasogeneratorom, aerodinamika projektila, aerodinamički otpor, numerička simulacija, numerička dinamika fluida.

\section{Определение сокращения сопротивления численным моделированием для снаряда с газогенератором}

\begin{abstract}
В полёте артиллерийского снаряда формируется область низкого давления непосредственно за снарядом, что приводит к образованию базового сопротивления, которое влияет на снижение скорости снаряда. Известно, что базовое сопротивление можно уменьшить или даже совсем устранить образуя поток горячего газа позади базы снаряда. Тот эффект, производимый этим потоком горячего газа, называется эффект истечения газа из газогенератора. В данной работе представлен внутренний баллистический расчёт конфигурации с газогенератором. Численное моделирование осесимметричного снаряда получено с использованием программного обеспечения Reynolds Averaged Navier-Stokes (RANS) computational fluid dynamics software (CFD). Кроме того, проводились испытания для двух моделей турбулентности с использованием полуэмпирических методов. Реализуемая к- $\varepsilon$ модель турбулентности была использована для расчёта аэродинамического сопротивления снаряда с газогенератором и без него. Полученные результаты показывают уменьшение базового сопротивления примерно на $12 \%$ в режиме сверхзвукового потока для конфигурации с газогенератором.
\end{abstract}




\title{
Détermination de la réduction de résistance par la simulation numérique pour le projectile à générateur de gaz
}

\begin{abstract}
Pendant le vol d'un projectile d'artillerie une région à basse pression se produit immédiatement derrière la base du projectile ce qui cause une résistance basique qui diminue la vitesse du projectile. Il est bien connu que la résistance de base peut être diminuée ou complètement éliminée par la formation du gaz chaud derrière la base du projectile. L'effet produit par ce courant du gaz chaud est appelé l'effet de fuite du générateur de gaz. Le calcul balistique intérieur de la configuration à générateur de gaz est présenté dans ce papier. La simulation numérique d'un projectile à axe symétrique a été réalisée par le logiciel Reynolds Averaged Navier-Stokes (RANS) computational fluid dynamics software (CFD). On a effectué aussi les essais pour deux modèles turbulents par des méthodes semi empiriques. Le réalisable $k-\varepsilon$ modèle de turbulence a été utilisé pour le calcul de la résistance aérodynamique du projectile avec ou sans générateur de gaz. Les résultats obtenus démontrent la réduction de la résistance de $12 \%$ environ dans le régime supersonique de courant pour la configuration à générateur de gaz.
\end{abstract}

Mots clés: projectile d'artillerie, projectile à générateur de gaz, aérodynamique de projectile, résistance aérodynamique, simulation numérique, dynamique numérique des fluides. 